This is an electronic reprint of the original article. This reprint may differ from the original in pagination and typographic detail.

Author(s): Saarinen, Taina

Title: Internationalization of Finnish higher education - is language an issue?

Year: $\quad 2012$

Version:

Please cite the original version:

Saarinen, T. (2012). Internationalization of Finnish higher education - is language an issue?. International Journal of the Sociology of Language, 2012(216), 157-173. https://doi.org/10.1515/ijsl-2012-0044

All material supplied via JYX is protected by copyright and other intellectual property rights, and duplication or sale of all or part of any of the repository collections is not permitted, except that material may be duplicated by you for your research use or educational purposes in electronic or print form. You must obtain permission for any other use. Electronic or print copies may not be offered, whether for sale or otherwise to anyone who is not an authorised user. 


\title{
Internationalization of Finnish higher education - is language an issue? ${ }^{1}$
}

\author{
Taina Saarinen
}

Forthcoming in 2012

in International Journal of the Sociology of Language, 216,

Thematic issue "Language variety, language hierarchy, and language choice

in the international university", edited by Hartmut Haberland and Janus Mortensen

\begin{abstract}
Finland is among the countries with the highest amount of English-taught programmes in higher education in Europe (Wächter and Maiworm 2008). This article analyses, how the higher education language situation of a small country with a marginal majority language (Finnish) and an official bilingual status (Finnish and Swedish) has historically developed from the setting of "drawing the line" between Finland and Sweden or Finland and Russia (Harle and Moisio 2000) in the 19th century and the early 20th century (nationalism), towards drawing the line between Finnish/Swedish and English in the late 20th century (globalization). It then continues to present a case of foreign language (in practice English) programmes in higher education as an example of the globalization development in Finnish higher education. The data for the article consists of the internationalization strategies for Finnish higher education, The Finnish International Study Programme Database, and introductory texts from four universities' and four polytechnics' International BA and MA programmes.
\end{abstract}

Keywords: Finnish higher education, internationalization strategies, English taught programmes

\section{Introduction}

As this article was being written, Finnish universities were preparing for a fundamental higher education reform of 2010, which had for the most part been motivated with the international attractiveness of Finnish universities (Ministry of Education 2009a). Finnish higher education has traditionally been seen as a nation state project (Klinge 1989, 1990; Anckar 2000). In recent years, however, the higher education developments and political demands for increased internationalization and student mobility (see Nokkala 2007; Garam 2009; Ministry of Education 2009a) have challenged this relatively stable and traditional understanding of higher education as, first and foremost, a national issue. Our higher education system has been adapted in many ways to meet the demands of the European Higher Education Area (Saarinen 2008). In the "new" university system it will be possible to commodify universities by allowing them to charge tuition fees for students coming from outside the EU. In addition, the new internationalization strategy for Finnish higher education, published in the beginning of 2009, calls for further measures towards internationalization (Ministry of Education 2009a). 
All these processes challenge Finnish higher education not only from the point of view of internationalization, but also from the fundamental perspective of universities and polytechnics $^{2}$ as national institutions (providing a public service) in a globalizing world. These structural changes also force the universities and polytechnics to rethink their language of tuition, as English increases its share in a system traditionally dominated by Finnish, and, to a smaller degree, Swedish.

Internationalization seems to have been a focal priority in Finnish higher education since the 1990s (Nokkala 2007), but the policies on and practical uses of languages in higher education - domestic or international - have remained unproblematized. While some attention has been paid to the use of national languages in research (see Hakulinen et al. 2009), the impacts of internationalization on policies and practices of university teaching have been largely unarticulated both in policy debates as well as by researchers.

\section{The language scene in Finnish higher education}

Linguistically, Finland is observed as traditionally fairly homogeneous - monolingual even - regardless of the country's official bilingual status. Reasons for this are several, as noted by Nuolijärvi (2005). Compared to other European countries, Finnish language minorities are historically relatively small (although existing). Geographically, the country is overwhelmingly Finnish speaking, and most of the Swedish speaking population has been located densely in particular geographical locations on the Western and Southern coast and the archipelago. (Latomaa and Nuolijärvi 2005.) The influx of migrant languages started later and slower than in many European countries, and only in the 1990s did the number of immigrants to Finland start to grow rapidly (see for instance Suni and Latomaa, forthcoming). While Finland has by no means entered the era of super-diversity as described by Vertovec (2006), the language landscape has been changed drastically by immigration during the last 10-20 years. (See Appendix for a more detailed description of the Finnish language situation.)

Until the late 1990s, the tuition language of universities was mostly Finnish, with the exception of two Swedish speaking and six bilingual (Finnish - Swedish) institutions. The new university law from 2009 did not change the situation in practice, although two bilingual universities will be merged with one Finnish language university into a bilingual one. Language distribution in the polytechnic sector looks rather similar: of the 26 polytechnics, two are Swedish and three bilingual.

In recent years, however, the demands for increased internationalization and student mobility have challenged this relatively hygienic, traditional understanding of universities as, first and foremost, a national project. Finland hosts the second largest (after the Netherlands) amount of foreign language study programmes in Europe, in proportion to the size of our higher education system (Wächter and Maiworm 2008; Garam 2009). Lehikoinen (2004: 46) suggests that Finland is spoken of as 'Little England' in Content and Language Integrated Learning (CLIL) circles, and, according to her, is now second choice for those students who have failed to get an exchange study place in the United Kingdom. 


\subsection{The historical development of language use in Finnish higher education}

The languages of tuition in Finnish higher education have since Independence in 1917 been Finnish and Swedish. In practice since the 1990s, and with the renewed University Law of 2004 also officially, English has been increasingly used in the higher education sector. This is a result of a longer historical development.

Finland, as a nation state, developed first as the Eastern part of the Kingdom of Sweden (until 1809), then as a Grand Duchy of the Russian Empire (1809-1917), and since 1917, as an independent republic. This development has placed geopolitical identification fronts first between Finland and Sweden, then between Finland and Russia (Harle and Moisio 2000), and later, linguistic fronts between Finnish and Swedish and English in the late 20th century.

The first Finnish university, the Royal Academy of Turku (Turun Akatemia, Regia Academia Aboensis), was founded on the western coast of Finland in Turku in 1640. Before that, Finns looking for higher education would travel to Paris, Prague, Rome, or to German universities. After the mid 1550s, the University of Wittenberg became especially popular among Finnish students.

At this time, Latin was the language of higher education in Finland and it remained so until the early 1800 s, i.e. also after the foundation of the Academy, not only because of its lingua franca status, but also because Latin was seen to educate and discipline the youth (Klinge 1987). The domestic challenge to Latin at the Royal Academy of Turku first came from Swedish rather than Finnish, since at that time, Finnish had barely begun to gain formal status as a written language. The written form of Finnish began to take form after the Reformation in the early and mid 1500s, mainly by Mikael Agricola, who translated the New Testament while studying at the University of Wittenberg, and produced several textbooks in Finnish. The first Finnish language grammar was published approximately 100 years later, in 1649 (Nuorteva 2006). However, during all of the Swedish reign in Finland (from the early Middle Ages until 1809), Swedish remained the language of the government. Finnish began to gain ground in official circles first as the language of church sermons, although informally Finnish was used increasingly in local government since the $16^{\text {th }}$ century (Hakulinen et al. 2009).

The unofficial use of the Finnish language continued and increased during the Russian Autonomy period starting in 1809, when Finland became a part of Russia. The name of the Academy was changed to The Imperial Academy of Turku (Keisarillinen Turun Akatemia). However, in 1827, the town of Turku practically burned to the ground, and the Academy suffered badly, with its valuable library destroyed. Consequently, in 1828 the Academy was moved to the new capital of the Grand Duchy of Finland, Helsinki, and renamed as the Imperial Alexander University to honour Alexander I, the Tsar of Russia who had gained a positive reputation as the first Grand Duke of Finland. As the geopolitical position of Helsinki was more favourable to the new rule than that of Turku, moving the university seemed the logical thing to do. 
The new Imperial Alexander University began to take model from the newly founded (1809) Berlin University (since 1828 Friedrich-Wilhelms-Universität and since 1949 Humboldt-Universität zu Berlin) and the Humboldtian ideals (Tommila 2006). At around the same time, the status of Latin as the language of tuition began to crumble, as Swedish increasingly started to gain ground as the language of the educated classes. Already at that time, however, more and more students were Finnish by mother tongue, although the first Finnish language oppikoulu (preparatory school for university) was not founded until 1858 . In 1863, Finnish was made an official language in administration.

In doctoral disputations, Latin remained the only language until 1852, when Swedish (and in 1858, along with the national romantic awakening, Finnish) was made an official language for doctoral disputations (Klinge 1987; Tommila 2006; Hakulinen et al. 2009). In 1871 , other languages were also given the status of language of dissertations, which meant that German quickly began to replace Latin as the lingua franca for Finnish scholars (Tommila 2006). The Language Act of 1863 stated that within a transition period of 20 years, Finnish would become equal to Swedish in all administrative matters. In 1894 a statute was made, declaring that all applicants for university teaching positions had to prove knowledge of Finnish (Hakulinen et al. 2009).

During the end of the $19^{\text {th }}$ century, and the national awakening, pressure towards using Finnish in the academia grew gradually. A short-lived (but very strongly experienced) backlash took place in the turn of the $20^{\text {th }}$ century, as the panslavistic russification movement strengthened in all of the Russian Empire, and the use of Russian was demanded in public offices and administration, including the university. For the remainder of the period of Autonomy, the official languages of the Grand Duchy of Finland were Finnish, Swedish and Russian (Hakulinen et al. 2009).

In spite of the gradual strengthening of the position of Finnish in the society and within the academic world, according to Tommila (2006), the first generation of Finnish speaking professors did not assume their seats until after the independence in the 1920s. After the independence of 1917, the question of language remained a hot issue long into the 1930s, both in higher education in particular and the society in general. The Constitution of 1919 declared Finland officially bilingual, and the University of Helsinki also retained its bilingual status, with teaching taking place in principle in relation to the students' languages.

During the first years of Independence, two new (private) universities were founded, both in Turku, and both based on language ideologies. The Swedish language Åbo Akademi (Åbo Akademi University) was founded in 1919, while the Finnish language Turun yliopisto (University of Turku) was founded in 1922. The reason behind this simultaneous promotion of both Finnish and Swedish language education was that the University of Helsinki was "becoming Finnish" either too quickly or too slowly, depending on which side of the language divide the person stood. In 1937, a decree was drafted which stated that the language of tuition at the University of Helsinki should be Finnish, but to guarantee the rights of the Swedish speaking students, a fixed number of Swedish speaking professors should be appointed (Tommila 2006; Klinge 1987).

After the Second World War, a steady massification of Finnish higher education started to take place, culminating in the 1960s with the influx of the post-war baby boom generations. Language issues had more or less been settled, with new universities being founded in 
Northern and Eastern Finland on regional policy principles (Kivinen et al. 1993) rather than language issues.

\subsection{Internationalization in Finnish higher education policy}

Higher education policy is a relatively well-researched area in Finland (Kivinen et al. 1993; Välimaa 1995; Saarinen 2007). Recent research covers aspects of internationalization both from the higher education system angle (Nokkala 2007) and from the point of view of academic staff mobility (Hoffman 2007). However, the language aspect of higher education - understood either as language policy or language education policy (see Pöyhönen and Luukka 2007) has been relatively under-researched as a policy level question. Language studies in Finnish higher education have been studied quite widely (see for instance Elsinen and Juurakko-Paavola 2006; Horppu and Lehtonen 2003; Kantelinen and Heiskanen 2004; Lahtonen and Pyykkö 2005; Niemi 2008; Nikula 2002; Pyykkö, Tuomi, Juurakko-Paavola and Fiilin 2007) but for the most part from the point of view of the structural organization of language education, language skills, and language curricula. The need for languages and language education, however, is more or less taken for granted and presented as self-evident, and research on language policies in higher education is even more sporadic.

Internationally, the literature on international study is more abundant, but seems to focus on aspects of international students and staff's experiences in a multilingual environment (see for instance Haberland et al. 2008). In international literature, linguistic aspects of higher education policy also seem rather non-existent, with some exceptions (for instance Hughes 2008).

The internationalization period in Finnish higher education started in late 1980s, and was at that time geared towards internationalization of research (Nokkala 2007). The first focus of systematic internationalization was on student and staff exchange programmes. The polytechnics sector, in fact, started to develop its own foreign language programmes already quite soon after the polytechnics were made permanent in the mid 1990s, and were in this respect forerunners to the universities. Since the turn of the Millennium, focus has been strongly on international (in practice English language) degree programmes instead of exchange programmes (Garam 2009.)

In the 1990s, internationalization was made into one of the performance based funding criteria (see Saarinen and Laiho 1997). The funding allocated by this criterion was relatively small, but it seems that it had a bigger influence on the development of internationalization (Melén-Paaso 1997, as quoted in Nokkala 2007). Also, higher education institutions were given funding to start building their English language programmes (Garam 2009).

According to Melén-Paaso (1997, as quoted in Nokkala 2007), the first internationalization developments and the participation in exchange schemes were implemented for the purpose of giving students skills in international working life cooperation. Studying in Finnish higher education is for the time being free to both domestic and international students, but the situation is will change with the new Higher education law in 2010, which grants universities the permission to collect fees from non-EU students. This coincides with the Minister of Education, Henna Virkkunen's statement of education as a 
new export industry for Finland (Ministry of Education 2009b). This strengthens the understanding of internationalization as an instrument for the commodification of Finnish (higher) education.

A new strategy for the internationalization of Finnish higher education institutions (Ministry of Education 2009a) was published in the beginning of 2009.

The strategy was commissioned as part of Prime Minister Matti Vanhanen's Centrecoalition Government program, titled A responsible, caring and rewarding Finland. International and its derivatives appear several dozen times throughout the government's program, but mostly within the context of general international relations, international (economic) competitiveness, and international crisis management. In fact, the only occurrence of international in the introduction takes place in the context of international security. This places the meaning of international in the government programme firmly in the realm of international juxtapositions and crises rather than international co-operation.

In the chapter of the Government Program dealing with education and culture, the internationalization strategy is operationalized simply as international mobility of students, teachers and researchers.

The general aim of the consequent internationalization strategy is "to create in Finland an internationally strong and attractive higher education institution and research community that promotes society's ability to function in an open international environment, supports the balanced development of a multicultural society and participates actively in solving global problems." (Ministry of Education 2009a: 10).

In the strategy (Ministry of Education 2009a), internationalization is discussed primarily in the context of increasing the competitiveness of our higher education system. Internationalization is asserted to increase quality, enhance the innovative and economic competitiveness of the universities in particular and society in general. The impression is clearly conveyed that internationalization is not 'business as usual', but rather a preoccupation of those who are 'at the top' or aiming in that direction.

The analysis of the strategy shows that it mostly positions the whole concept of internationalization as a cross-border activity, either external to Finland or as an inwardly directed action, from the international realm towards the national realm. It seems that international is related with phenomena within Finland only in relation to immigration. In the internationalization discourse of the new strategy, internationalization strategies are needed to control the almost force-of-nature like globalization, but that internationalization has very little to do with "Finnish" society. But should the strategy be more concerned about what internationalization is doing within Finland than with what Finland is doing with regard to internationalization?

In the strategy for internationalization, a certain air of self-evidence prevails. Internationalization is described as something that has taken place unproblematically and, as self-evidently, produces only positive effects to everybody concerned:

Internationalization of higher education, research and innovation systems is at the core 
of societal renewal. Moreover, internationalization of higher education institutions promotes diversity in the society and business community, international networking, competitiveness and innovativeness, as well as improves the well-being, competence and education of the citizens. (Ministry of Education 2009a: 9)

Studying and working abroad improve the individual's language skills and position in the labour market and increase understanding between cultures and societies. (Ministry of Education 2009a: 17)

\section{Foreign language programmes ${ }^{3}$ : challenging the national language setting?}

Measured by the share of English taught programmes against all programmes, Finland ranks second in Europe after the Netherlands. Measured by the proportion of institutions providing English language programmes, Finland ranks first in Europe. (Wächter and Maiworm 2008.) These international programmes seek to answer the challenges of internationalization in two ways: by offering degree programmes to students who have no knowledge of Finnish, and by preparing Finnish students for the increasingly international professional life where English is often used as a lingua franca.

In 1996, there were approximately 75 English language programmes in universities and polytechnics; in 1999 this had almost doubled. In December 2008, there were 287 international degree programmes at universities and polytechnics. These were overwhelmingly English; two were run in Swedish (the other national language in Finland), and five in "other" languages, which means Finnish and Fenno-Ugric degree programmes offered for foreigners.

Until 2008, there were more Finnish students going abroad than foreign students coming in; only now the tide has turned the other way, as slightly more foreign students come in than Finnish students go out (Garam 2009). All this intensifies pressures on foreign (in practice English) language tuition in Finnish higher education.

The University Law from 2004 states that a university may decide to use other languages than its language of tuition in teaching. This made it also officially possible for universities (and, similarly, polytechnics) to offer foreign language degree programmes; a development, which had started already in the late 1990 s especially in the polytechnics and later also in universities (Pyykkö 2005).

\subsection{Position of languages on the policy level}

In the strategy for internationalization of higher education (Ministry of Education 2009a), the increase in "foreign language" programmes is closely linked with strategic goals of internationalization of higher education. In short, from the point of view of languages, the strategy focused on:

- Improving international study programmes especially from the viewpoint of 
language skills of the teaching staff;

- Teaching national languages for foreign students and staff;

- The strengthened position of English presented both as self-evident (foreign language $=$ English) and as a problem from the point of view of domain loss of national languages.

It seems that while the goals are set for a mix of Finnish and foreign students, the foreign language programs in Finnish higher education in fact attract more foreign than Finnish students (Garam 2009). Thus, the goals of "home internationalization" and a mix of home and international students are not realized.

On the other hand, according to Garam (2009), approximately $35 \%$ of programmes have not defined their target audience. It seems that the newer the programme, the more likely it is to be directed at international students, whereas the older programmes from the 1990s target their student selection also to domestic students. It seems that universities are even more geared towards attracting international students than polytechnics (Garam 2009).

Also the strategy for internationalization makes constant references to "foreign language education" when in fact the education takes place practically only in English:

The higher education institutions offer high-quality education focused on their fields of expertise, given in foreign languages. (Ministry of Education 2009a: 26)

Even when the de facto position of English is explicitly acknowledged, reference is still made to foreign languages in plural:

Higher education institutions have increased education given in foreign languages leading to a qualification. In proportion to the size of our higher education sector, there is an exceptionally large amount of teaching available in English. (Ministry of Education 2009a: 14)

\subsection{How do "foreign languages" appear in international degree programmes?}

According to Hughes (2008), English-speaking countries offer more than $50 \%$ of programmes involving students studying abroad. This "Anglophone asymmetry" (Hughes 2008: 111) may lead to questions of equality and equity, as non-Anglophone countries (such as Finland and Netherlands in Wächter and Maiworm's 2008 study) resort to offering programmes in English to attract international students.

Tella et al. (1999: 26) suggest in their evaluation of foreign language teaching in Finnish higher education that the general feeling among programmes and courses at the end of the 1990s was that "foreign language is just a tool" and that "English is just the medium of instruction". In their findings, the learning of "foreign languages" (i.e. English) was presented as self-evident: English was "picked up through extensive exposure", showing an instrumentalist view of (foreign) language. In their recommendations, Tella and others stated that "more attention should be paid to the role, significance, and, until now, hidden potential of the foreign language when organising a programme through a F[oreign] L[anguage]" (1999: 65-66). 
However, this same air of self-evidence is still seen, 10 years later, in the Strategy for internationalization (Ministry of Education 2009a) and programme descriptions:

The higher education institutions require that teachers teaching in a foreign language demonstrate their skill in the teaching language by a language degree or in some other way determined by the higher education institution. (Ministry of Education 2009a: 20)

I analyzed the data from international master's programmes at four universities (University of Helsinki, University of Turku, University of Jyväskylä and Helsinki University of Technology) and four polytechnics (Metropolia Polytechnic, Laurea Polytechnic, Turku Polytechnic and Jyväskylä Polytechnic). I took the introductory texts from the organizations' web pages and analyzed them to see, whether these introductions generally about 100 words in length - made any mention of language(s) or culture(s). Four categories in relation to languages emerged:

1. Knowledge of English is presented as a basic and necessary entry qualification.

2. Implicit or explicit reference is made to participation in the study programme giving language skills or intercultural skills.

3. Languages and/or communication and/or intercultural skills are mentioned specifically as program contents.

4. No particular reference is made to languages or culture.

Out of the 73 English language programmes in the data, 40 made no mention of languages in their web introductions whatsoever. This implies that languages - in this case, English are taken as self-evident in the so-called foreign language degree programmes in Finland. This self-evidence can take place at least on two levels:

First, it is taken for granted that the language is English and none other. Any other language would be mentioned. This reminds us of the Danish historical situation, as described by Mortensen and Haberland (this issue), where Latin as the teaching language was not mentioned in the University of Copenhagen statutes from 1732, apparently because of its obvious nature. The position of English in the Finnish society as the "third domestic language" (see Leppänen et al. 2008) makes it unnecessary to name the language specifically as English.

Second, it is possible that the language of tuition is not mentioned, because language is seen instrumentalistically, merely as a tool. As such, it is irrelevant what the language in question is. This is reminiscent of Tella and others' (1999) findings in their evaluation of the foreign language programmes of the 1990s.

Twenty-one programmes made either implicit or explicit reference to mere participation in the programme giving intercultural skills; very few of these, however, made reference to "foreign languages", and even fewer to any particular language:

You will study in an intercultural and enthusiastic environment and learn together with students from all over the world. (Information Technology, Metropolia Polytechnic) 
The teaching language of the programme is English. During your studies you will get to know students from all around the world. (Bioinformatics, Helsinki University of Technology)

You will be trained fully in English to become a professional of media and journalism - to face the new challenges globalisation presents to media industries and to journalism. (Media and Global Communication, University of Helsinki)

The studies take place in a multicultural atmosphere as the students come from different countries. (Facility Management, Laurea Polytechnic)

[DP] is delivered in English. The students learn professional competences in transnational and multi-domestic environment and with international dimension in the curriculum. (Business Management, Laurea Polytechnic)

As the program is truly international, with students from different cultures and with different backgrounds, you will have a great opportunity to improve your interpersonal and interoperability skills. Furthermore, all courses are given in English so you will also improve your language skills. (Information Technology, Turku Polytechnic)

Seven programmes stated that the programme content included language and / or cultural contents.

Five programmes made specific reference to the necessary knowledge of English as a prerequisite to starting studies.

In particular in technical and natural science fields, while there are big numbers of programmes, there is little or no mention of (multi)languages or (multi)culture. Skills in English are mostly mentioned as a prerequisite for studies rather than an aim of studies:

The applicants must have a very good command of English. (Helsinki University of Technology)

Languages are seldom mentioned as any kind of motivation for international programmes. This might suggest, in spite of the recommendations made by Tella et al. (1999) a decade ago, that foreign languages - in the Finnish context, overwhelmingly English - are still seen as a tool rather than a mediator.

The programmes' profiles for universities and polytechnics seem similar, if both Bachelor and Master's level programmes are taken into account. If only Master's programmes are taken into account, it seems that the polytechnics' programmes have made no reference to the self-evident understanding of "foreign language" programmes giving English skills. For universities, the situation seems different: almost one-third of the universities implied this. 
This difference may have its explanation in the different histories of universities and polytechnics. The polytechnics started earlier with the international programmes and stabilized their practices before universities. Universities, on the other hand, may feel that they have traditionally been international and have consequently not problematized the role of language. Consequently, they are now in a situation where they need to "make language visible" in a way they are not used to.

\section{Concluding remarks: The euphemistic "foreign" and the paradox of internationalization}

It seems that while the stated purpose of introducing, developing and supporting foreign language programmes in Finnish higher education is largely motivated by demands for increased internationalization of higher education, languages do not play a role in the vocalized policies. The hot Finnish language debates of the 1920s and 1930s have eased into a situation where language of teaching is no longer named or problematized. But what happens in higher education, when language becomes invisible?

An interesting aspect in the language setting of Finnish higher education internationalization is the fact that while international degree programmes are taught overwhelmingly in English, they are euphemistically referred to as "foreign language programmes". Why the euphemistic usage of "foreign" for "English"? This euphemism may imply willingness in principle to promote languages other than English - a steady policy goal since the 1990s (Tella et al. 1999). However, it might also be due to an unwillingness to specifically acknowledge the strong position of English in the Finnish society (see Hakulinen et al. 2009 for a criticism of English and Leppänen et al. 2008 for an analysis of English in Finland.) This is not merely a question of official, Ministry-level policy. It also seems that the departments and universities prefer to talk about "foreign language" education, even if it is practically totally in English (see for instance Lahtonen 2005; Tella et al. 1999; Garam 2009).

Officially, the aim of Finnish internationalization is both to attract foreign students and to internationalize Finns. However, we can ask, whether these are indeed compatible aims, and what kind of internationalization is promoted by presenting English language degree programmes as self-evidently international. Also in the follow-up evaluation of teaching through foreign languages (Lahtonen and Pyykkö 2005), the language of tuition is not really questioned. This seems to reflect a paradox, also discussed by Risager (this issue): internationalization of higher education may be leading towards linguistic homogeneity instead of linguistic diversity. 


\section{Appendix: The linguistic situation of Finland}

Legally, the main frame for language policies is set in the Constitution and other legislation, whereby languages spoken in Finland can be set in four categories, depending on their legal status. (Mantila 2005)

First, the strongest status is with the national languages (Finnish and Swedish), which are stated in the Constitution (originally 1919, renewed in 1999) and in the Language law (originally 1922, renewed in 2003). Legally, Finnish and Swedish have an equal status.

Second, Sami languages have been given status by a separate law on the Sami language (2003), which states the linguistic and cultural rights of the Sami population.

Third, the Constitution specifically mentions Romani and Sign languages as minority languages, with particular rights.

Fourth, in addition to the above mentioned, the Constitution states that all other language groups have the right to develop their language and culture. With the increase in especially migrant languages, this right is interpreted in very different ways.

Currently, there are approximately 80 languages with more than 100 mother tongue speakers. According to Statistics Finland, of the 5.3 million inhabitants, about 4,850,000 people ( $91 \%$ of population) speak Finnish. The number of Swedish speakers is 290,000 (5.5\% of population). The number of Russian speakers has increased in recent years into almost 50,000. About 22,000 people reportedly speak Estonian. The national minorities of Romani (approximately 14,000) and Sami (approximately 2,000), Finnish sign language $(5,000)$ and Finnish-Swedish sign language $(200)$ add to the picture. However, it has to be noted that sign languages and Romani are not registered by Statistics Finland as mother tongues. Another problem with these statistics is that Statistics Finland assumes that each person can only have one mother tongue; in other words, bilingualism or multilingualism is not observed in the statistics.

\section{Notes}

${ }^{1}$ Partly based on Saarinen et al. (2008).

2 There is a controversy in Finland about the names of the institutes in the vocational tertiary or "Ammattikorkeakoulu" sector, leading to Bachelor's and nowadays to some extent Master's level degrees in work-related tertiary level. The Ministry of Education uses the term "Polytechnic", while the institutions themselves prefer "University of Applied Sciences". In this article, the term "Polytechnic" is used consistently to avoid confusion with the university sector.

${ }^{3}$ As a high-ranking Ministry education official, Anita Lehikoinen (then head of Division for Higher Education and Science, now director of Department for Education and Science Policy) noted in 2004, "We try to avoid speaking about English-language education; we always say foreign language education and everybody knows that in practice it means English, only English." (Lehikoinen 2004.) I will discuss this euphemistic usage of "foreign language" for de facto English language teaching towards the end of the paper. 


\section{References}

Anckar, Olle. 2000. University education in a bilingual country: The case of Finland. Higher Education in Europe 25(4). 499-506.

Elsinen, Raija \& Taina Juurakko-Paavola. 2006. Korkeakouluopiskelijoiden ruotsin kielen taidon arviointi [Assessment of Swedish skills of higher education students]. HAMKin julkaisuja 4/2006. Hämeenlinna: Hämeen ammattikorkeakoulu.

Garam, Irma. 2009. Vieraskieliset tutkinto-ohjelmat suomalaisissa korkeakouluissa [Foreign language degree programmes in Finnish higher education institutions]. Helsinki: CIMO.

Haberland, Hartmut, Janus Mortensen, Anne Fabricius, Bent Preisler, Karen Risager \& Susanne Kjærbeck (eds.). 2008. Higher education in the global village. Roskilde: University of Roskilde.

Hakulinen, Auli, Jyrki Kalliokoski, Salli Kankaanpää, Antti Kanner, Kimmo Koskenniemi, Lea Laitinen, Sari Maamies \& Pirkko Nuolijärvi. 2009. Suomen kielen tulevaisuus. Kielipoliittinen toimintaohjelma [Future of Finnish. Language Policy Programme]. Kotimaisten kielten tutkimuskeskuksen verkkojulkaisuja 7. http://www.kotus.fi. Helsinki: Kotimaisten kielten tutkimuskeskus.

Harle, Vilho \& Sami Moisio. 2000. Missä on Suomi? Kansallisen identiteettipolitiikan geopolitiikka ja historia [Where is Finland? The geopolitics and history of national identity]. Tampere: Vastapaino.

Hoffman, David. 2007. The career potential of migrant scholars in Finnish higher education: Emerging perspectives and dynamics. Jyväskylä: University of Jyväskylä Press.

Horppu, R. \& T. Lehtonen. 2003. Monipuolinen kielitaito? Selvitys Helsingin yliopistosta valmistuneiden kieliopinnoista [Versatile language skills? Study of language studies of Univeristy of Helsinki graduates]. Opintoasiainosaston julkaisuja 22/2003. Helsinki: Helsingin yliopisto.

Hughes, Rebecca. 2008. Internationalisation of higher education and language policy: Questions of quality and equity. Higher Education Management and Policy 20 (1), 111-128.

Kantelinen, Ritva \& M. Heiskanen. 2004. Ammattikorkeakoulujen kieliopinnot [Language studies at polytechnics]. Joensuun yliopisto: Soveltavan kasvatustieteen laitos.

Kivinen, Osmo, Risto Rinne \& Kimmo Ketonen. 1993. Yliopiston huomen. Korkeakoulupolitiikan historiallinen suunta Suomessa [The future of the university. The historical direction of Finnish higher education policy]. Helsinki: Hanki ja jää.

Klinge, Matti (ed.). 1987. Helsingin yliopisto 1640-1990, osa I: Kuninkaallinen Turun Akatemia 1640 - 1808 [University of Helsinki 1640-1990, part I: Royal Academy of Turku 1640-1808]. Helsinki: Otava.

Klinge, Matti (ed.). 1989. Helsingin yliopisto 1640-1990, osa II: Keisarillinen Aleksanterin Yliopisto 1808-1917 [University of Helsinki 1640-1990, part II: Imperial Alexander University 1808-1917]. Helsinki: Otava.

Klinge, Matti (ed.). 1990. Helsingin yliopisto 1640-1990, osa III: Helsingin yliopisto 1917-1990. [University of Helsinki 1640-1990, part III: University of Helsinki 19171990]. Helsinki: Otava.

Lahtonen, Suvi. 2005. Korkeakoulujen vieraskielisen opetuksen seurannan vastausten tarkastelu [Follow-up of foreign language study at universities: observing answers]. In Suvi Lahtonen \& Riitta Pyykkö. Korkeakoulujen vieraskielisen opetuksen arvioinnin seuranta. KKA. Verkkojulkaisuja 6:2005. http://www.kka.fi /pdf/muut/muut julkaisut/KKA200506_korkeak.pdf (11 October, 2009)

Lahtonen, Suvi \& Riitta Pyykkö. 2005. Korkeakoulujen vieraskielisen opetuksen arvioinnin seuranta [Follow-up of foreign language study at universities]. KKA. 
Verkkojulkaisuja

6:2005.

http://www.kka.fi

/pdf/muut/muut_julkaisut/KKA200506_korkeak.pdf (11 Octobre, 2009)

Latomaa, Sirkku \& Pirkko Nuolijärvi. 2005. The language situation in Finland. In Robert

B. Kaplan \& Richard B. Baldauf Jr. (eds.), Language planning and policy. Europe, vol. 1: Finland, Hungary and Sweden, 125-232. Clevedon: Multilingual Matters.

Lehikoinen, Anita. 2004. Foreign-language-medium education as national strategy. In R. Wilkinson (ed.), Integrating content and language: Meeting the challenge of a multilingual higher education, 41-48. Maastricht: Universitaire Pers.

Leppänen, Sirpa, Tarja Nikula \& Leila Kääntä (eds.). 2008. Kolmas kotimainen. Lähikuvia englannin käytöstä Suomessa [The third domestic language. Case studies on the use of English in Finland]. Helsinki: SKS.

Mantila, Harri. 2005. Suomi kansalliskielenä [Finnish as a national language]. In Marjut Johansson \& Riitta Pyykkö (eds.), Monikielinen Eurooppa. Kielipolitiikkaa ja käytäntöä, 300-315. Helsinki: Gaudeamus.

Melén-Paaso, Monica. 1997. Erasmus-ohjelman tausta ja alkuvaiheet Suomessa [The background and initial stages of Erasmus programme in Finland]. In: In Erasmus, Sokrates ja Suomi. Korkeakoulutuksen eurooppalainen ulottuvuus 1992-1997. Helsinki: Centre for International Mobility.

Ministry of Education. 2009a. Strategy for the internationalisation of higher education institutions in Finland 2009-2015. Helsinki: Ministry of Education.

Ministry of Education. 2009b. Composite news bulletin, November, 2009. http://www.minedu.fi/OPM/Tiedotteet/composite_news_bulletins/2009/November.ht ml?lang=en

Niemi, Hannu. 2008. Korkeakoulututkintoihin kuuluvan ruotsin kielen taidon osoittaminen. Korkeakoulujen ruotsinopettajien käsityksiä virkamiesruotsin merkityssisällöistä ja sen taitotasovaatimusosan toteutumisesta [Showing required Swedish skills in higher education degrees]. Acta Universitatis Ouluensis, E: 99.

Nikula, Tarja. 2002. Kieliaineiden opetussuunnitelmahanke Jyväskylän yliopistossa. Jyväskylän yliopiston humanistisessa tiedekunnassa lv. 2001-2002 toteutetun hankkeen raportti [Curriculum project in language studies at the University of Jyväskylä] . Jyväskylän yliopisto: Soveltavan kielentutkimuksen keskus.

Nokkala, Terhi. 2007. Constructing the ideal university: The internationalisation of higher education in the competitive knowledge society. Tampere: Tampere University Press.

Nuolijärvi, Pirkko. 2005. Suomen kielet ja kielelliset oikeudet [Finnish languages and linguistic rights]. In Marjut Johansson \& Riitta Pyykkö (eds.), Monikielinen Eurooppa. Kielipolitiikkaa ja käytäntöä, 283-299. Helsinki: Gaudeamus.

Nuorteva, Jussi. 2006. Academic studies and research in Finland from the Middle Ages until 1809. In Päiviö Tommila \& Aura Korppi-Tommola (eds.), Research in Finland A history, 21-45. Helsinki: Helsinki University Press and the Federation of Finnish Learned Societies.

Pöyhönen, Sari \& Minna-Riitta Luukka. 2007. Kohti tulevaisuuden kielikoulutusta. Kielikoulutuspoliittisen projektin loppuraportti [Towards future language education policy]. Jyväskylän yliopisto: Soveltavan kielentutkimuksen keskus.

Pyykkö, Riitta. 2005. Vieraskielisen opetuksen muuttuva konteksti [The changing context of foreign language teaching]. In Suvi Lahtonen \& Riitta Pyykkö. Korkeakoulujen vieraskielisen opetuksen arvioinnin seuranta. KKA. Verkkojulkaisuja 6:2005. http://www.kka.fi /pdf/muut/muut_julkaisut/KKA200506_korkeak.pdf (11 October, 2009)

Pyykkö Riitta, Ulla-Kristiina Tuomi, Taina Juurakko-Paavola, \& Ullamaija Fiilin. 2007. Uutta yhteistyötä ja profiilien terävöittämista: korkeakoulujen kielikoulutus [New kind of cooperation and sharpening profiles]. In Teoksessa Sari Pöyhönen \& Minna-Riitta 
Luukka (eds.), Kohti tulevaisuuden kielikoulutusta. Kielikoulutuspoliittisen projektin loppuraportti, 123-15. Jyväskylä: Jyväskylän yliopisto.

Risager, Karen 2012. Language Hierarchies at the International University. International Journal of the Sociology of Language 216:XXX-XXX

Saarinen, Taina \& Irma Laiho. 1997. Tuloksellisuuden ja laadun palkitseminen: viiden maan vertailu [Rewarding for productivity and quality: a five country comparison]. In Teoksessa Kari Nyyssölä \& Taina Saarinen (eds.), Näkökulmia korkeakoulujen tuloksellisuuteen, 33-51. Koulutussosiologian tutkimuskeskuksen raportti 41. Turku: Turun yliopisto.

Saarinen, Taina. 2007. Quality on the move. Discursive construction of higher education policy fom the perspective of quality. Jyväskylä Studies in Humanities 83. Jyväskylä: Jyväskylän yliopisto.

Saarinen, Taina. 2008. Whose quality? Social actors in the interface of transnational and national higher education policy. Discourse: studies in cultural politics of education 29(3). 179-193.

Saarinen, Taina, Tarja Nikula \& Sari Pöyhönen. 2008. The language situation in Finnish higher education - from a nationalist project towards answering multilingual demands. Paper presented at CALPIU '08, Roskilde, 14-16 December.

Suni, Minna \& Sirkku Latomaa.Forthcoming. Finnish school - a multilingual paradise for plurilingual pupils? In Jan Blommaert, Sirpa Leppänen, Päivi Pahta, and Tiina Virkkula (eds.). Dangerous multilingualism. Palgrave. Tella, Seppo, Anne Räsänen \& Anne Vähäpassi. 1999. Teaching through a foreign language. From tool to empowering mediator. Publications of higher education Evaluation council 5:1999. Helsinki: Edita.

Tommila, Päiviö. 2006. Research and the origins of research policies (1809-1917). In Päiviö Tommila \& Aura Korppi-Tommola (eds.), Research in Finland - A history, 47-69. Helsinki: Helsinki University Press and the Federation of Finnish Learned Societies,.

Vertovec, Steven. 2006. The emergence of super-diversity in Britain. Centre on Migration, Policy and Society. Working Paper No. 25. Oxford: University of Oxford.

Välimaa, Jussi. 1995. Higher education cultural approach. Jyväskylä: University of Jyväskylä.

Wächter, Bernd \& Maiworm, Friedhelm. 2008. English-taught programmes in European higher education. The picture in 2007. ACA papers on international cooperation in education. Bonn: Lemmens. 